\title{
Magical Amulets, Magical Thinking, and Semiotics in Early Byzantium
}

\author{
Jacquelyn Tuerk-Stonberg \\ Kean University, Department of History, Union, NJ, USA \\ jacquelyn.stonberg@gmail.com
}

Organized by Chen Zhi and his team, Research Centre for History and Culture of Beijing Normal University (Zhuhai Campus) \& Beijing Normal University - Hong Kong Baptist University United International College

\begin{abstract}
The term 'magic' is problematic. Magic studies have rapidly developed in recent decades and have suggested various ways of understanding the term, especially regarding objects from the medieval Roman Empire, Byzantium. Two early Byzantine amulets (as case studies) display conventional semiotic structures, which include persuasive analogy, speech-acts, and show-acts. Persuasive analogy, speech-acts, and show-acts - and how they organize information - operate also in religious, medical, and philosophical examples. Accordingly, art, archaeology, and texts of ritual power exemplify intersecting communities of thought and various types of social practices. Magic studies is interdisciplinary, and it encourages critique of modern assumptions regarding authority and of our intellectual colonization of times past. This essay is broad with several object examples across media, written as a conference presentation. Another approach to these semiotic structures on magical amulets - with examination of fewer objects and wider attention to the historiography of magic studies - will appear in the forthcoming Oxford Handbook on Byzantine Art and Architecture, ed. Ellen Schwartz.
\end{abstract}

\section{Keywords}

Byzantine - magic - amulet - speech acts - show acts - persuasive analogy 
Language - whether verbal, visual, or performative - roots the communicator within a community.* Language can be understood as the product of finding and creating meaning in signs by relating them to something in the world. It is powerful enough to shape human experience - to express and thus realize one's feelings. And it can do so communally through recognition by others, whether those others are people, gods, or demons.

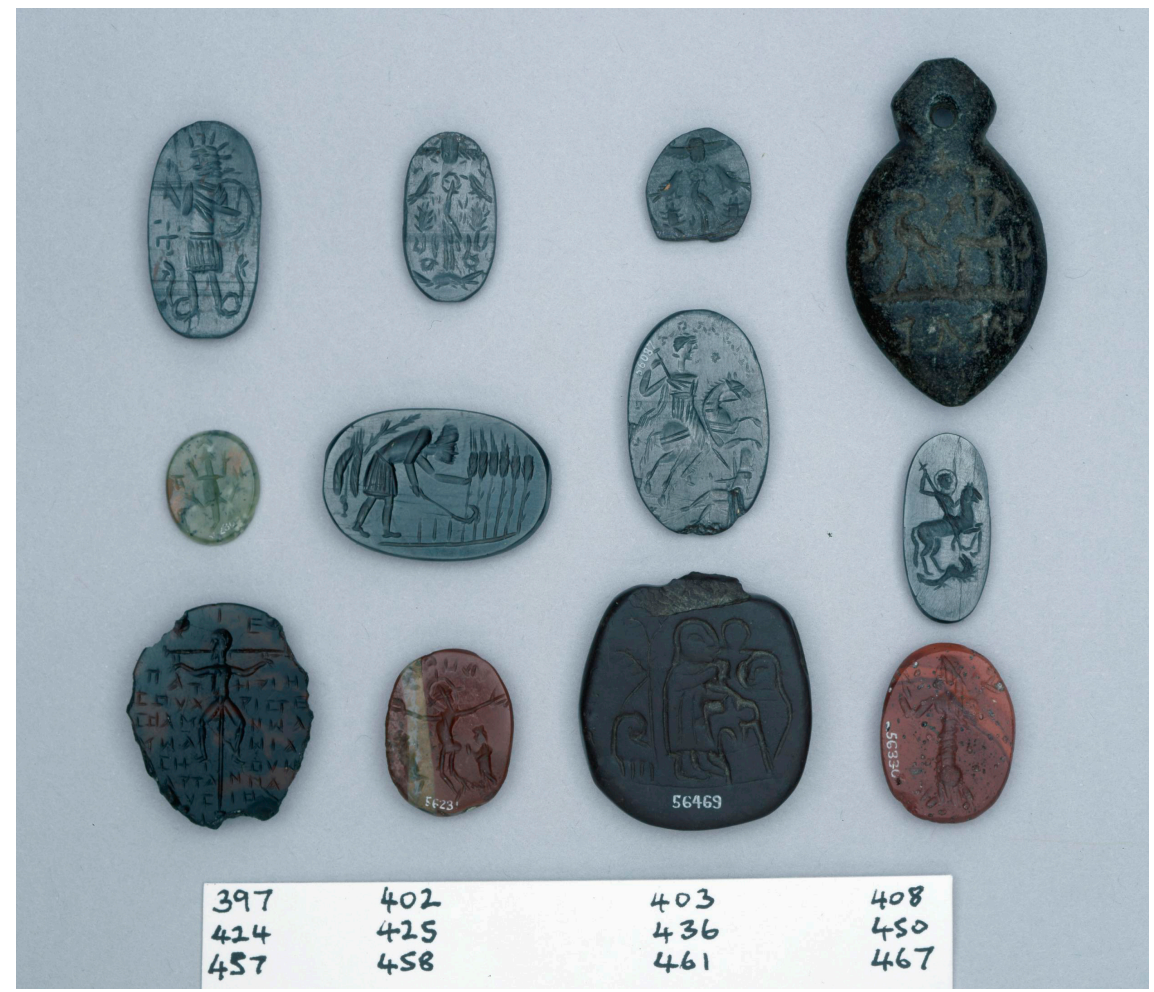

FIGURE 1 Magical gems 4th-5th c., British Museum, Michel inv. nos. listed in the photo WWW.BRITISHMUSEUM.ORG/COLLECTION/OBJECT/H_OA-9717

LICENSED UNDER CC BY-NC-SA 4.0 (C) THE TRUSTEES OF THE BRITISH MUSEUM

* This article was the keynote presented at the Asian Conference on the Ancient World International Academic Conference session on "the Ancient Middle East and Ancient Mediterranean," 29 January 2021. 
Language directed toward gods and demons often appears on magical objects that were designed to realize desires, needs, and fears. These amulets were common and widespread throughout the Mediterranean and across centuries, which is evident from the hundreds of surviving material examples (see examples in Fig. 1). ${ }^{1}$ This abundance of examples attests to great numbers of producers and clients alike. Large communities believed in magical objects because they believed in the power of visual and verbal language to interpret and shape human realities.

Ritual power in the late antique Mediterranean was multicultural and multi-practical, rooted in Jewish, Greek, Roman, Egyptian, Coptic, Babylonian, Syrian, and Arabic traditions, predating or simultaneous to the growth of Christianity. ${ }^{2}$ In Greek, magic ( $\left.\mu \alpha \gamma \varepsilon i \alpha\right)$ was a wide-ranging topic which could involve an individual spell ( $\dot{\varepsilon} \pi \omega \delta \dot{\eta})$, love potion ( $\varphi \dot{i} \lambda \tau$ pov), or amulet ( $\pi \varepsilon p i \alpha \pi \tau \circ v)$,

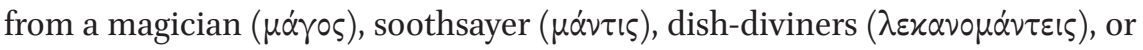

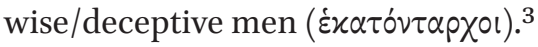

Scholars have debated the term 'magic' for generations, applying the term to images and texts used in healing, cursing, divination, and exorcism. Today, the term 'magic' is used by scholars of the ancient Mediterranean to explore medical, religious, and household objects, from bowls to papyri, amulets, and jewelry ${ }^{4}$ (as in Figs. 2-4). Our modern choice of terms shapes the very questions that we bring to these late antique objects. Thanks to contemporary scholars, the term 'magic' is no longer used to mean 'incorrect science' or 'incorrect religion.' Magic overlaps (rather than competes) with religion and medicine. Magical thinking - regardless of venue - is an act of faith in which individual belief itself, embedded in language, is the seat of power.

1 The publications are vast; a useful sample includes: Entwistle \& Adams 2011; Michel 20o1; Faraone 1999; Kotansky 1994; Meyer \& Mirecki 1995; Meyer \& Smith 1994; Faraone \& Obbink 1991; Daniel \& Maltomini 199o; and Betz 1986.

2 Budge (2011) established the multiculturalism of so-called magical amulets in his work, originally entitled Amulets and Superstitions (1930). Since then scholars have explored and challenged these cultural boundaries. The scholarship is vast; some representative examples are: Frankfurter 2019a; Nagy et al. 2019; Bortolani 2019; Faraone 2018; Peers 2018; De Bruyn 2017; Boschung \& Bremmer 2015; Dasen \& Spieser 2014; Regulski 2012; Bohak 2008; Shaked 2005; Mirecki \& Meyer 2001; Dickie 2001; Maguire 1995; Mathews 1999. A useful introduction to Byzantine amulets is Bosselmann-Ruickbie (2019).

3 Fögen (1995:100-103) explains some of these terms as they appear in the Greek commentary by Theodore Balsamon (1140-1199 CE) on canon 61 of the Council in Trullo in the year 691/692, which addresses vocabulary used in the fourth century by the Church Fathers. The other terms are mentioned by Abrahamse (1982:6).

4 Dasen 2014:177-191; Faraone 2012; Entwistle \& Adams 2011; Spier 2007; Bozóky 2003; Entwistle 2003; Michel 20o1; Maguire et al. 1989; Vikan 1984:65-86; Abrahamse 1982:3-17; Smith 1978; Magoulias 1967-68:228-269; Bonner 1950. 


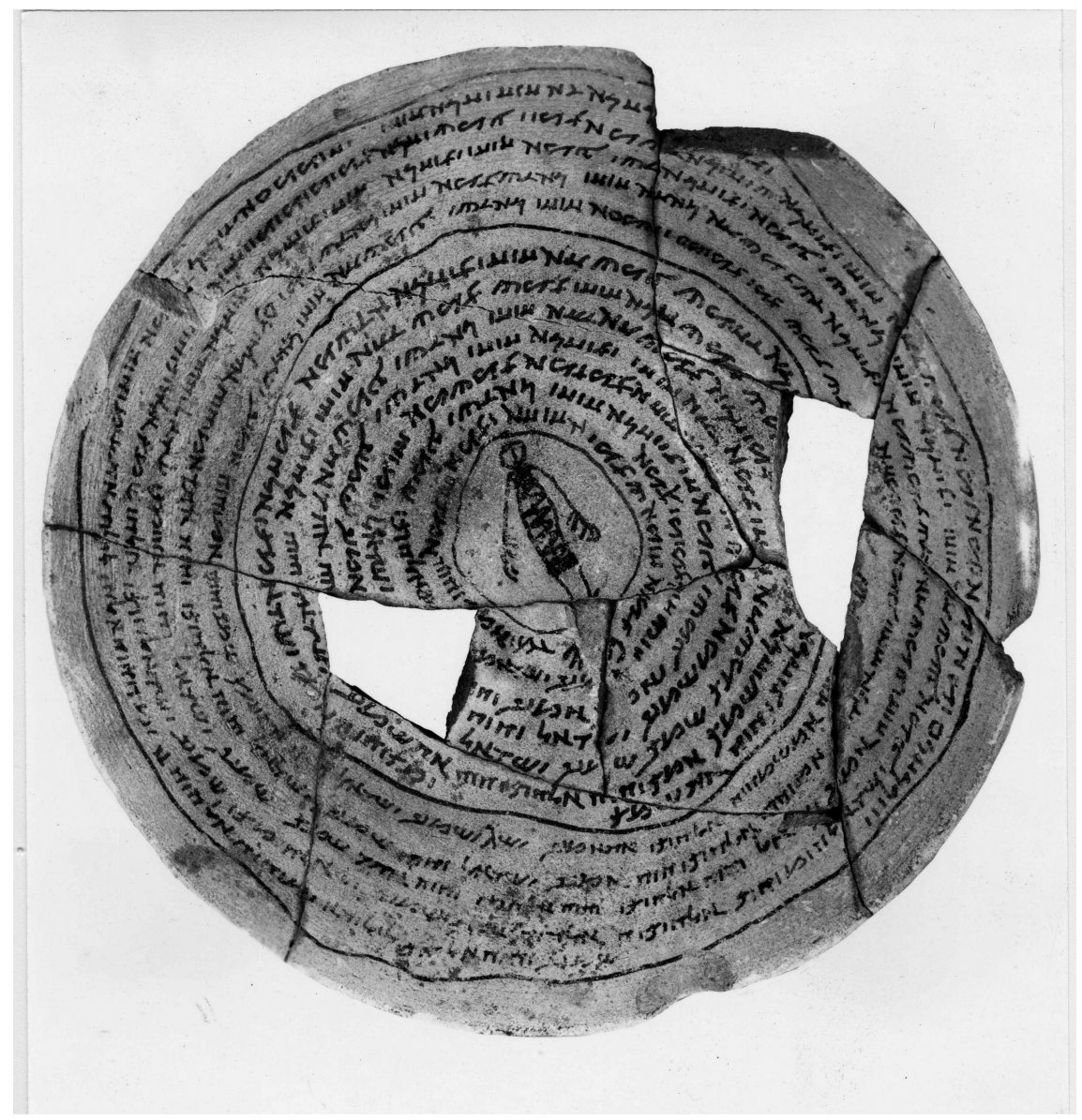

FIGURE 2 Incantation bowl, with image of a demon inscribed in Aramaic spiral text, pottery, $14.20 \mathrm{~cm}$ diameter, $3.80 \mathrm{~cm}$ depth, Late-Post Sasanian, 6th-8th c., British Museum 117885 , registration number $1980,0415 \cdot 30$

WWW.BRITISHMUSEUM.ORG/COLLECTION/OBJECT/W_1980-0415-30, LICENSED UNDER CC BY-NC-SA 4.0 ( THE TRUSTEES OF THE BRITISH MUSEUM

Magical thinking is apparent in thousands of healing and protective amulets, jewelry, textiles, pottery, papyri, liturgies, and miraculous icons. Icons were credited with winning battles and healing diseases. But perhaps even more so than miracle-working icons, amulets were relied upon for practical help and protection. About half of the surviving late antique texts concerning magic reveal spells of healing or protection. These texts include the magical texts themselves, ${ }^{5}$ ancient manuals for how to make amulets, and non-magical texts

5 Faraone 2018; Mirecki \& Meyer 2001; Faraone 1999; Kotansky 1994; Meyer \& Smith 1994; Faraone \& Obbink 1991; Daniel \& Maltomini 199o; Betz 1986. 


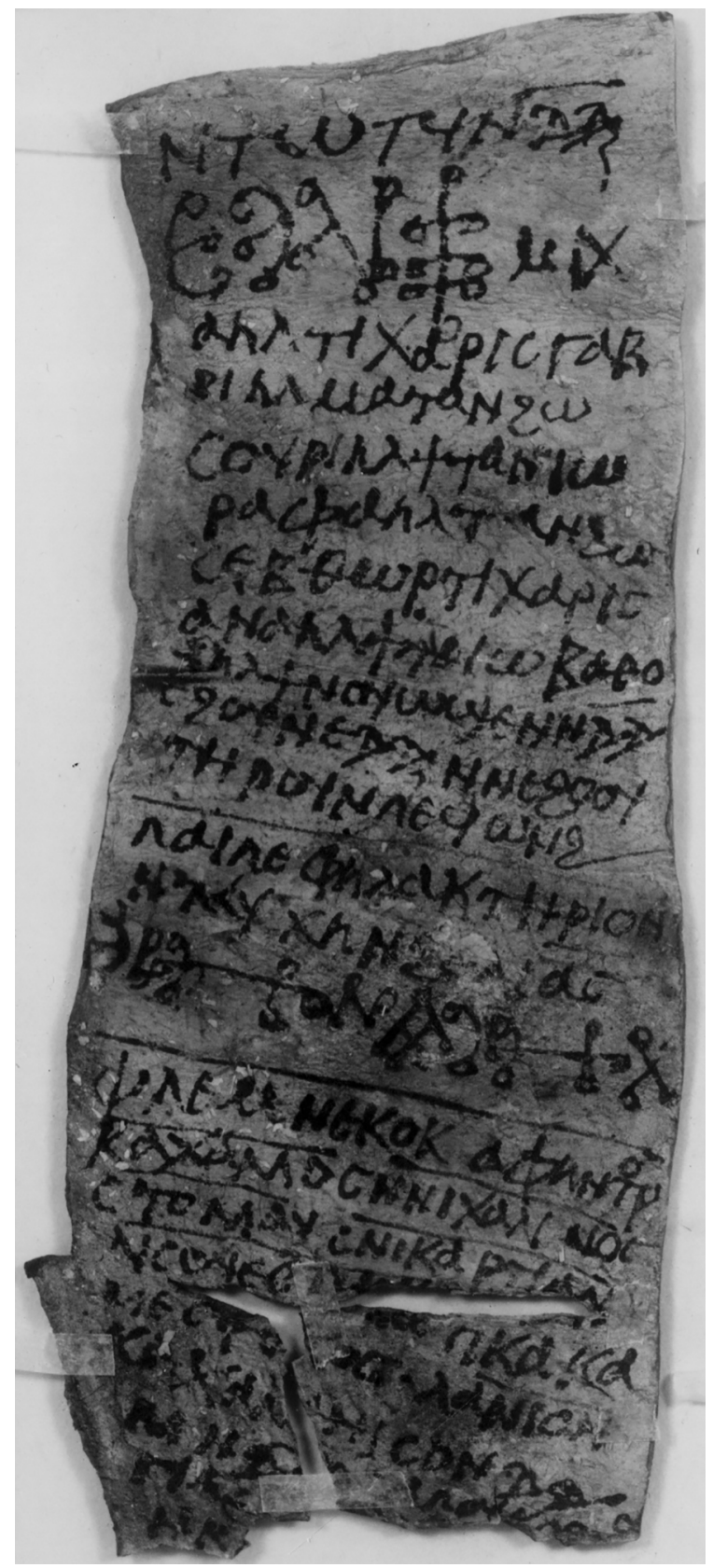

FIGURE 3 Manuscript containing magical spells for favor, honour and passion, leather, $1.53 \mathrm{~cm}$ (max.) x $6.5 \mathrm{~cm}$ (max.), Coptic, 6th-7th c. British Museum, EA1o434,b, from Robert James Hay, 1868 WWW.BRITISHMUSEUM.ORG/COLLECTION/OBJECT/Y_EA10434-B, LICENSED UNDER CC BY-NC-SA 4.0 (C) THE TRUSTEES OF THE BRITISH MUSEUM 


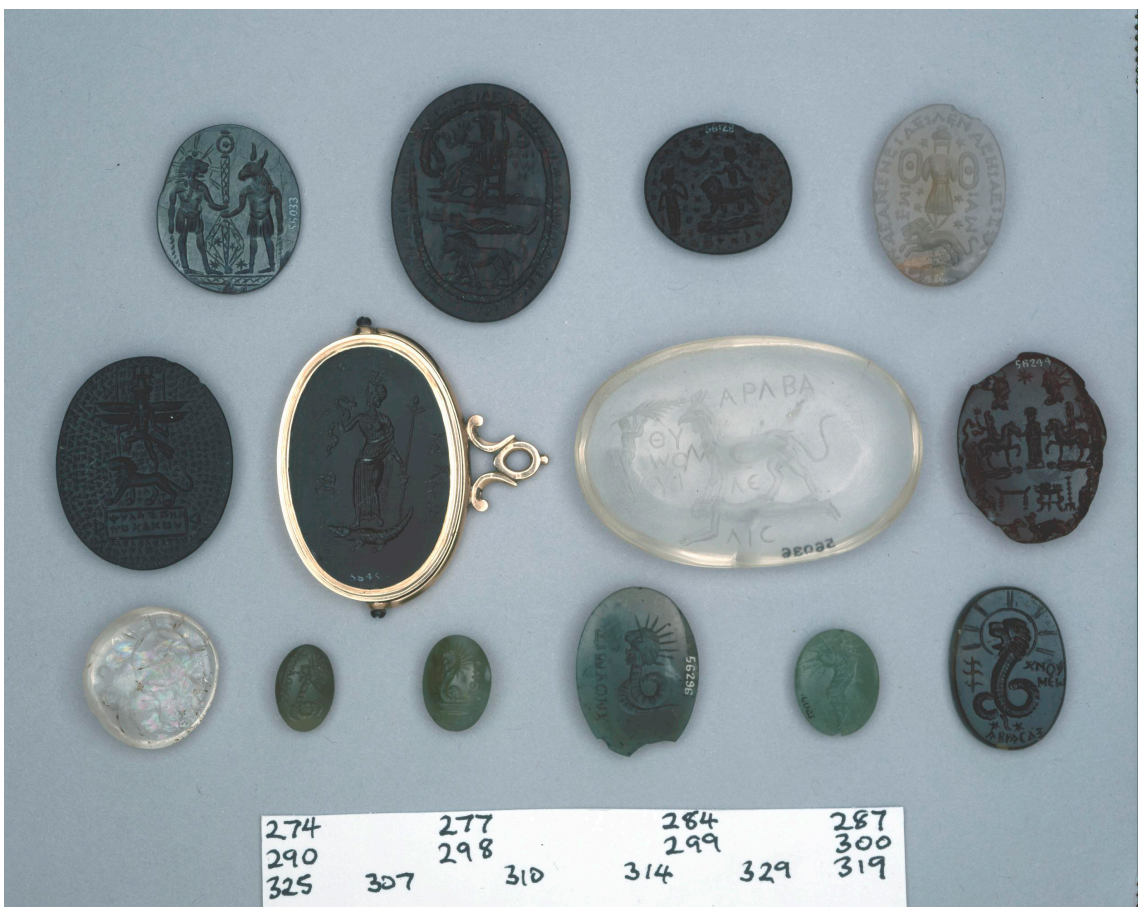

FIGURE 4 Magical gem; intaglio, 3rd c., British Museum, Michel inv. nos. listed in the photo WWW.BRITISHMUSEUM.ORG/COLLECTION/OBJECT/H_OA-10040, LICENSED UNDER CC BY-NC-SA 4.0 (C) THE TRUSTEES OF THE BRITISH MUSEUM

about amulets. Other practical uses included spells for love, sex, and reproduction, such as the Life of St. Anthony the Younger (785-865 CE) in which the saint is said to have used a parchment spell to cure infertility. ${ }^{6}$ Expectations for what amulets could do, however, does not explain how they did it, if at all.

Regardless of any faith in supernatural powers, the words and images themselves on these objects create their own power. Several semiotic strategies contribute to this power. In particular, the use of analogy was one such semiotic strategy to give authority to expression.

A dark red hematite amulet made in Byzantine Egypt in the 6th century used analogy to cure uterine bleeding (see Fig. 5). There were social as well as medical reasons to make and wear such an amulet. ${ }^{7}$ It was designed to be

6 Published in Kitzinger (1954:83-150).

7 Branham (2002:20, notes $38 \& 39$ ) discusses at length the taboo surrounding menstruating women in the presence of the sacred: a menstruating (impure) woman coming into contact with the body of Christ would have defiled him. The fact that the bleeding woman touched his robe, not his actual body, has been historically used both to keep menstruating women out of sacred spaces (citing Theodore of Tarsus, 668-69o CE) and to justify their admittance into 


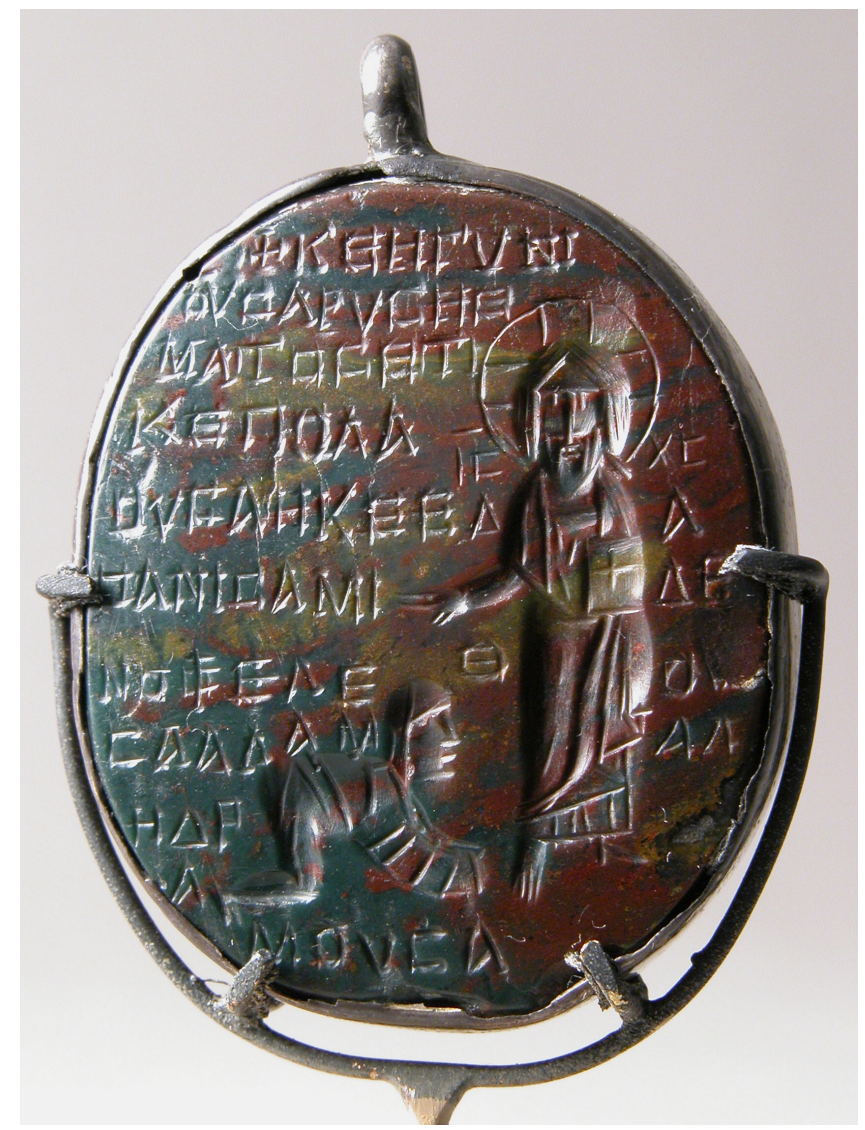

FIGURE 5 Amulet carved in intaglio, with inscription and image of Christ healing the woman with an issue of blood, Coptic Egypt, early Byzantine, 6th-7th century, incised hematite, silver mount, 5 × 3.7 x 1 cm, The Metropolitan Museum of Art, New York, \#17.190.491, Gift of J. Pierpont Morgan 1917

WWW.METMUSEUM.ORG, OPEN ACCESS PUBLIC DOMAIN, LICENSED UNDER CC ZERO

sacred spaces, citing Gregory the Great, bishop of Rome (590-604 CE), Epistola 64, in Migne (1862: vol. 77, cols 1183-1199). Pliny the Elder, 23/24-79 CE (Natural History, Bk. vii, ch. (13) 15, para. 2 "Remarkable Circumstances Connected with the Menstrual Discharge"), characterises the proximity to menstruating people as causing must to become sour, seeds to become sterile, grafts to wither away, garden plants to parch up, and fruit to fall from the tree; even her glance will dim mirrors, blunt steel, take away the polish from ivory, and kill bees; the blood causes brass and iron to rust, and if tasted it will drive dogs mad. 
worn around the neck and is engraved with an image and text that together portray a familiar story from the Gospel of Mark (5:25-35), the healing of the woman with the issue of blood. ${ }^{8}$ The amulet reads: "And a woman being with a flux of blood came, having suffered and having spent much, she benefited nothing."9 The inscription describes her failed attempts at a cure, whereas the image describes her successful cure: touching Jesus' garment.

The story continues on the other side of this same amulet: "but rather, she had known the source of her flow of blood was dried up in the name of her faith" (see Fig. 6). The text of the amulet is slightly different from the Gospel text and so it may have been specifically designed for use on this amulet. Accompanying the inscription is an image of a female 'orant' with her arms raised in a gesture of thanksgiving. The orant giving thanks is not mentioned in the Gospel and so may represent the Byzantine person who wore this amulet, expressing gratitude for an expected cure. The amulets' text and image create an analogy between the woman from the Bible story and the Byzantine person who wore this amulet, presumably to address uterine bleeding. The material of this blood-controlling amulet is significant in that the hematite stone is analogically linked to the Greek word for blood, ai $\mu \alpha$. This red-veined bloodstone used to treat uterine bleeding was recommended by Pliny the Elder (b. 23/24-79 CE)

8 Translation of Mark 5:25-35 is in Berry (1943): "And a woman, having been in a flow of blood for twelve years, and suffering many things by many physicians, and having spent all her money, and nothing having been profited but rather having come to the worse, hearing the things about Jesus, coming in the crowd behind (him) she touched his garment. She said: If only I may touch his garments I shall be healed. And immediately her fountain of blood was dried up, and she knew in her body that she was cured from the plague. And immediately, Jesus, knowing that power had gone forth from himself, turning in the crowd he said: Who touched my garments? And he said to her: Daughter, your faith has healed you." Also see the Gospel of Luke 8:43-49 and the Gospel of Matthew 9:20-22. However, these two other versions do not include the spending of much money and much suffering that is in the Gospel of Mark and on the amulet.

9 The amulet reads exactly, with a few letters illegible: “+ КЕНГVNI / OVCAPVCHE /

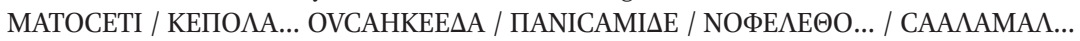

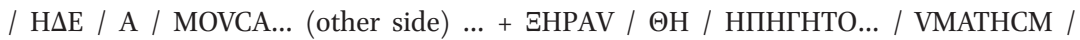
OVAVTHCENTO / NOMATIT / HCПICTEOCAV / TIC." It is transliterated and translated by Lieselotte Kotzsche in Weitzmann (1979:\#398) but still with nonstandard spelling: "KE

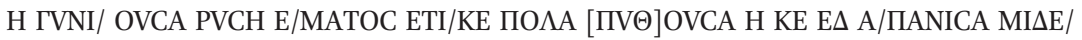
N OФЕ $\Lambda \mathrm{E} \Theta O[\mathrm{EI}] / \mathrm{CA} A \Lambda A$ MA $\Lambda[\Lambda \mathrm{ON}] / \mathrm{H} \Delta \mathrm{E}$ A/MOVCA... (other side) $[\mathrm{E}] \mathrm{EHPAV} / \Theta \mathrm{H} /$ H ПНГН TO[V]/ VMATHCM/ OV AVTHC ENTO/ [O] NOMATI T/HC ПICTEOC AV/TIC." It is also transliterated in Bol (1983:\#165). Spellings of the Greek text have been altered in transliteration for the sake of clarity. However, I do not believe that this means the amulet's text is "misspelled" or "corrupt," but only that modern scholars of Greek prefer a codified grammar and spelling, when in practice no language is consistently bound by its own "rules." 


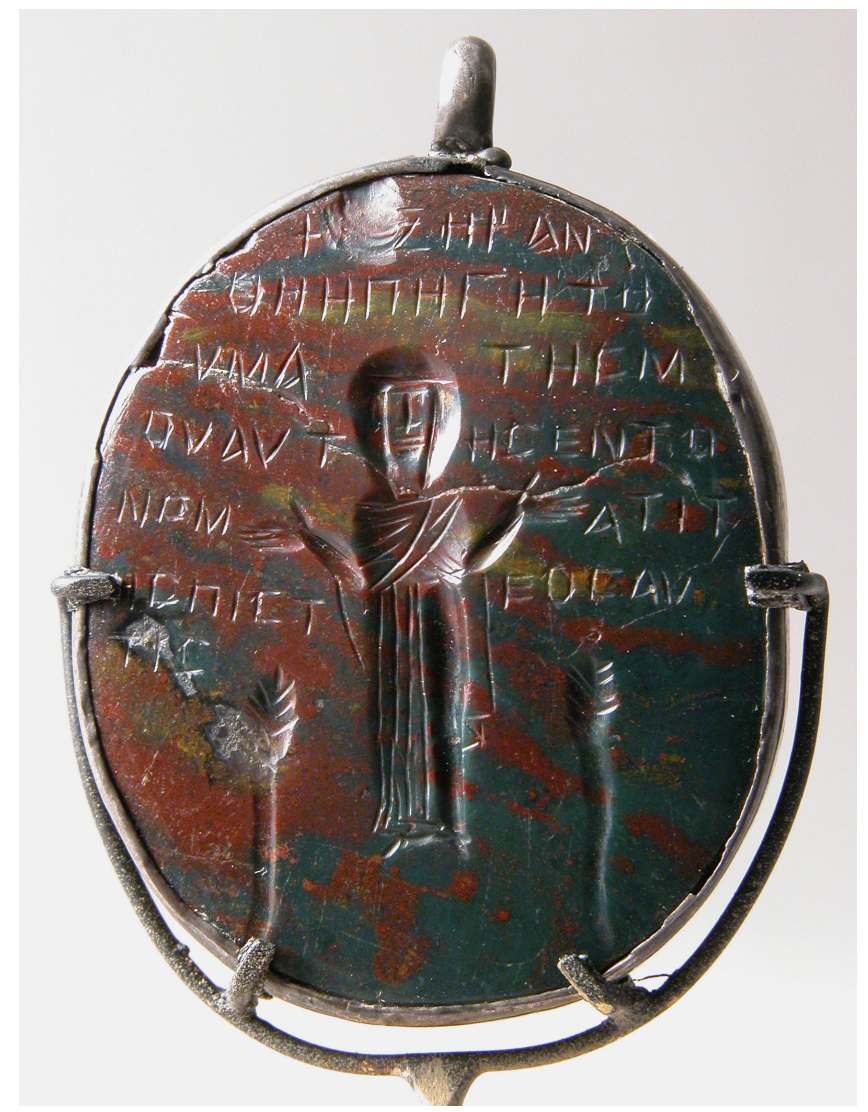

FIGURE 6 Amulet carved in intaglio, with inscription and image of Christ healing the woman with an issue of blood, Coptic Egypt, early Byzantine, 6th-7th century, incised hematite, silver mount, 5 × 3.7 x 1 cm, The Metropolitan Museum of Art, New York, \#17.190.491, Gift of J. Pierpont Morgan 1917 WWW.METMUSEUM.ORG, OPEN ACCESS PUBLIC DOMAIN, LICENSED UNDER CC ZERO

in Natural History and Soranus of Ephesus (b. $98 \mathrm{CE}$ ) in Gynecology. ${ }^{10}$ The hematite amulet's use of analogy stems from a larger late antique context of analogy. Several Hippocratic medical texts show that analogy was considered to be an important part of medical practice. For instance, the Hippocratic text, On Breaths, makes analogy between the vaporization of humors in the human body and boiling water. Another Hippocratic text, On Diseases IV, explains the coagulation and separation of the humors with an analogy to the manufacture of butter and cheese. And Nature of the Child explains gestation

10 Pliny the Elder in Natural History 36.37.145 and 36.8.147; Soranus of Ephesus in Gynecology 3.42.3. 


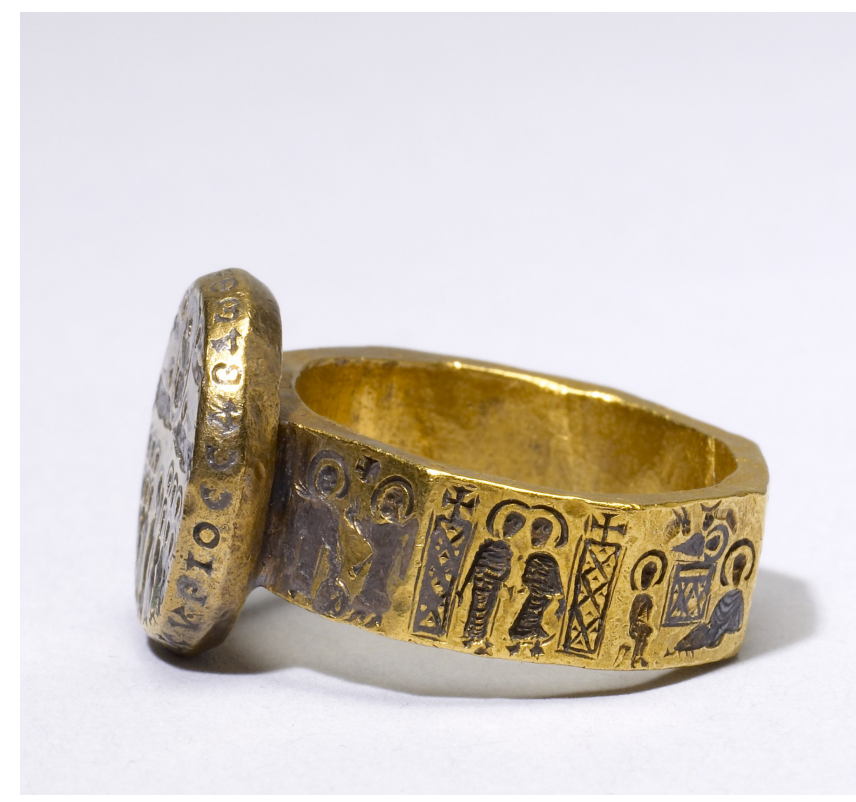

FIGURE 7 Marriage ring with scenes from the life of Christ, gold with niello, $1.7 \times 2.3 \times 2.6 \mathrm{~cm}$, Egypt, Byzantine, 6th-7th century, The Walters Art Museum, Baltimore, \#45.15 LICENSED UNDER CC, ART.THEWALTERS.ORG/DETAIL/11447/MARRIAGE-RINGWITH-SCENES-FROM-THE-LIFE-OF-CHRIST/

through analogy with the formation of crust on bread. ${ }^{11}$ These ancient Greek Hippocratic models for how to use analogy in scientific experiments survived into late antiquity through doctors including Alexander of Tralles (ca. 525-6o5 $\mathrm{CE})$ and Galen (129 - ca. $216 \mathrm{CE})$ who made wide usage of the Hippocratic texts.

Alongside ancient Greek medical arts, rhetorical arts also make use of persuasive analogy. The rhetorician, Philostratus (ca. 170-247/250 CE), in his textbook Images on the rhetorical method of ekphrasis, teaches that if a speaker can create an analogy between his subject and the audience, then that speech will be powerful enough to move the hearts and minds of the listeners. In philosophy too, Greek sources commonly used analogy as a means to organize knowledge, as in the texts On Signs and Inferences by the Epicurean philosopher Philodemus (110-35 B CE), and Against the Mathematicians, by the doctor and semiotician Sextus Empiricus (b. ca. 16o CE). Throughout ancient Greek and late antique thought, analogy was persuasive and authoritative.

11 On Breaths, ch. 12; On Diseases IV, chs. 51-52; Nature of the Child, chs 17 and 29. 


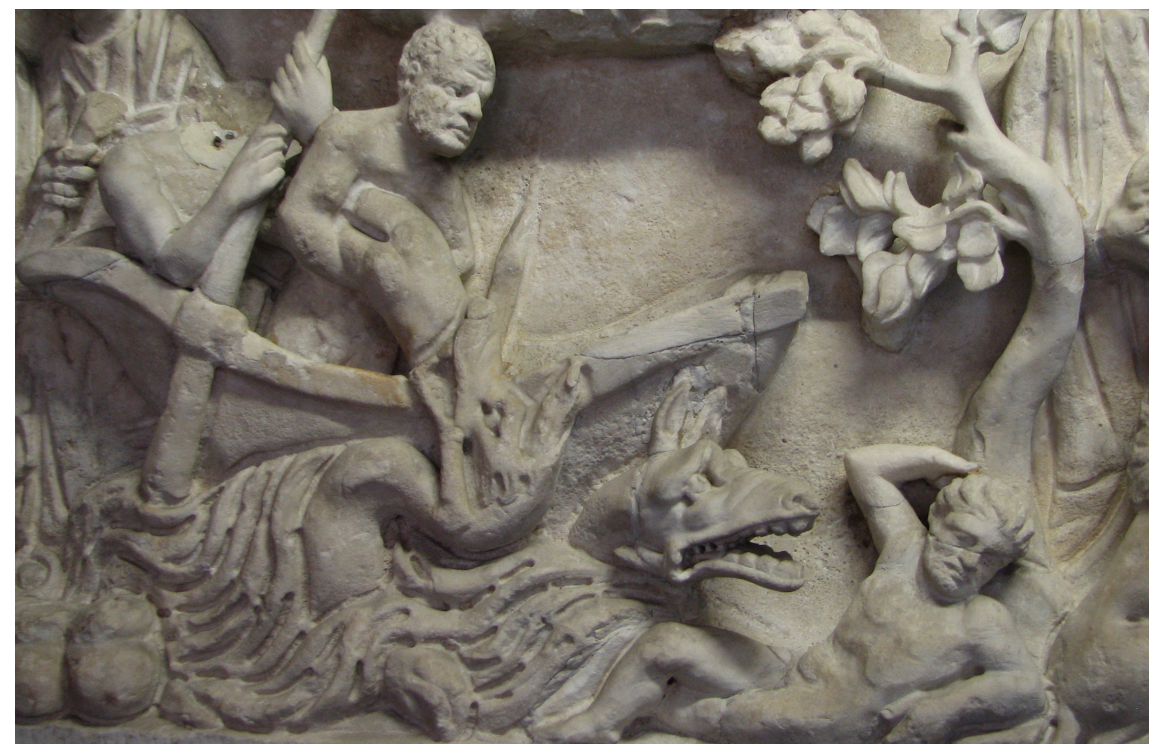

FIgURE 8 Detail from a sarcophagus depicting Jonah, marble, Christian Roman, 5th c., Vatican Museum, Museo Pio Cristiano LAWRENCE OP, WWW.FLICKR.COM/PHOTOS/PAULLEW/8492133480/IN/PHOTOSTREAM/, LICENSED UNDER CC BY-NC-ND 2.0

The Greek tradition of persuasive analogy also appears in late antique artworks that shape concepts of physical and spiritual well-being. Early Christian marriage rings depict the birth of Jesus as an analogy for one's own fertility in marriage (as in Fig. 7). ${ }^{12}$ Catacomb paintings and sarcophagus sculptures create analogy between sacred stories of spiritual salvation and personal desire for salvation, with the visual statement: God save me the way you saved Jonah from the sea monster or the Three Youths from the furnace (as in Figs. 8-9). The persuasive analogy on the hematite amulet is not unusual. The placement of the Biblical text onto the amulet associated the real-life story of the Byzantine amulet-wearer with the holy story of salvation. It is a visual statement: may Jesus heal the Byzantine person as he healed the woman in the Biblical story.

By understanding the persuasive analogy of the hematite amulet, we can better understand the function of other powerful words and images to persuade and empower. A $5^{\text {th }}$ century papyrus amulet contains drawings and demonic characters with a text that reads "Christ arose, amen. He has woken to judge the living and the dead. You too, fever with shivering, flee from Kale, who wears this phylactery...[drawings and characters]... Holy inscription and mighty signs, chase away the fever with shivering... Now now now, quickly

12 Vikan 1984:83ff. For more on marriage rings, see Walker (2002:59-78). 


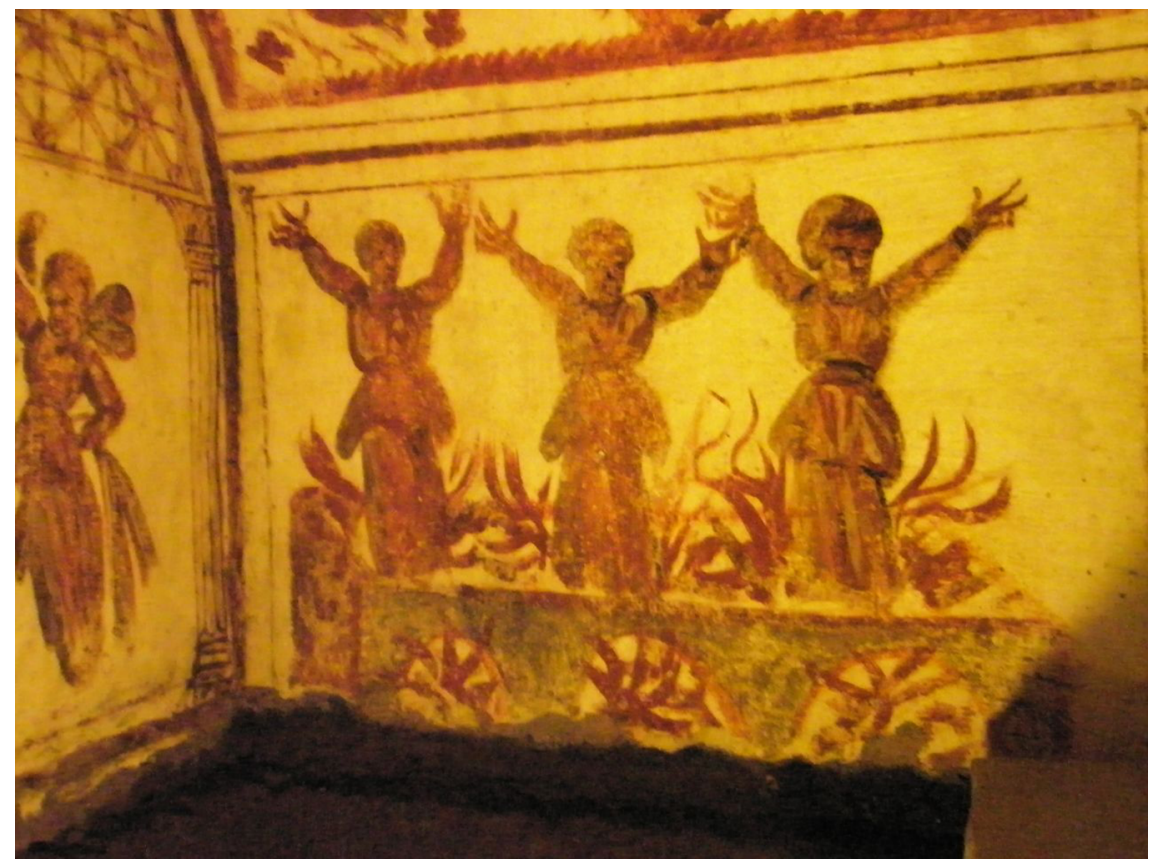

FIGURE 9 Three Youths in the Fiery Furnace, Via Latina Catacombs, Early Christian WHATDIDTHEROMANSEVERDOFORUS, WWW.FLICKR.COM/PHOTOS/14722341 @N03/2721432413/, LICENSED UNDER CC BY-NC-SA 2.0

quickly quickly."13 This inscription makes a persuasive analogy between Jesus' power to heal and the power of the amulet to heal fever.

A late antique hematite gem now in the British Museum depicts a rider spearing a baby-snatching demon as a persuasive analogy to keep one's baby safe with the visual statement equivalent to: attack my demon too. On the other side of the pendent is the inscription "СФРА/ГІС $/$ ЕOY" which translates as "Seal of God" (see Fig. 10). ${ }^{14}$ It is representative of hundreds of examples of this common iconography; for iconographic comparison in a different material, see Fig. $11 .{ }^{15}$ An amulet in blue glass from Cyprus depicts Daniel between two lions as a persuasive analogy: protect the wearer as Daniel was protected,

13 See \#23 in Daniel \& Maltomini 199 o.

14 Magical gem, British Museum OA.9576. https://www.britishmuseum.org/collection/ object/H_OA-9576.

15 For scholarship on seals: Peers 2018; Bohak 1996; Maguire et al. 1989. Further material examples: University of Chicago Smart Museum \#1988.56 and \#1988.57, Princeton University Art Museum \#31-34, Dumbarton Oaks \#50.15, Walters Art Museum \#54.2653, and Kelsey Museum \#26119. See Patera on the demon Gylou (2006:311-327). 


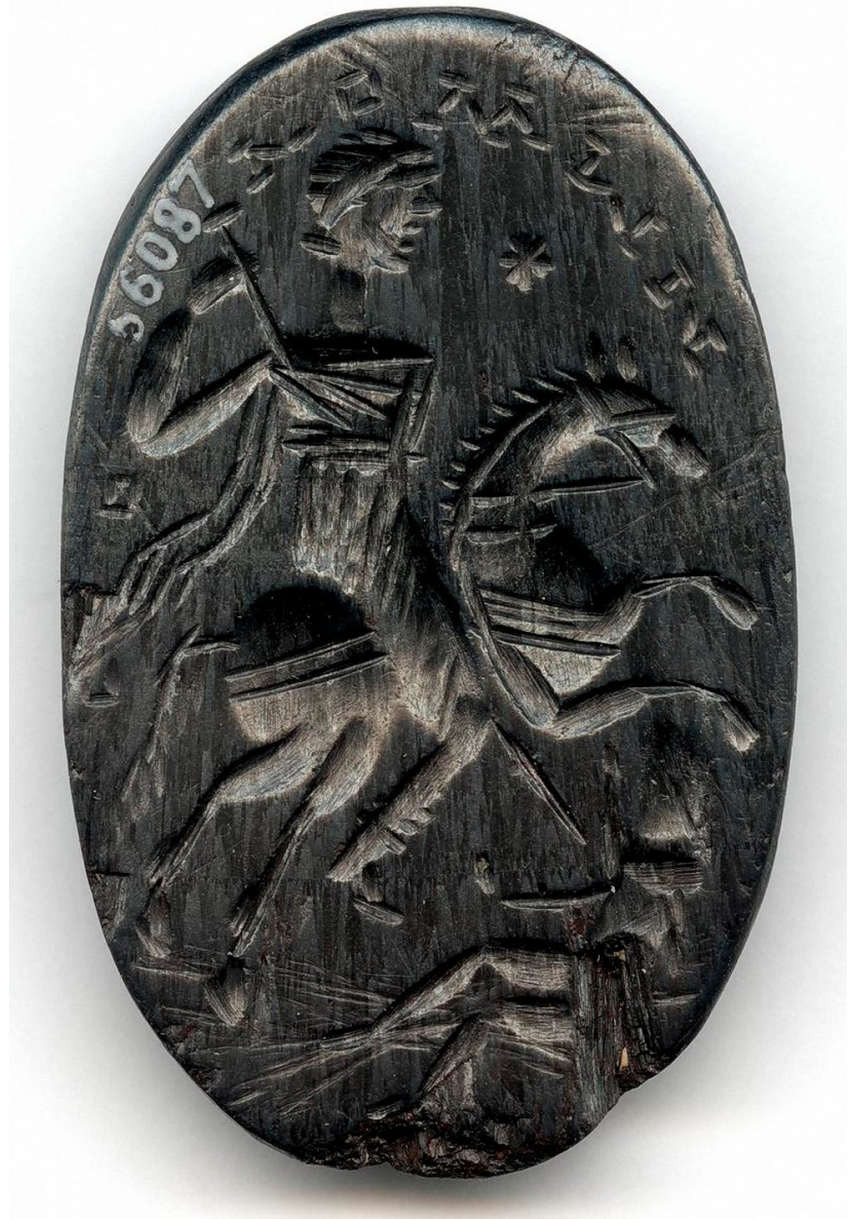

FIGURE 10 Magical gem; intaglio, 4th c., British Museum OA. 9576 WWW.BRITISHMUSEUM.ORG/COLLECTION/OBJECT/H_OA-9576, LICENSED UNDER CC BY-NC-SA 4.0 (C) THE TRUSTEES OF THE BRITISH MUSEUM

again, representative of this common iconography (see Fig. 12). ${ }^{16}$ The analogies in these contexts are based not on specific theological or scientific tenets but rather on general ways of knowing, expressing, and getting what one wants. Whenever a strategy for organizing experience (such as persuasive analogy) appears in multiple venues (medicine, rhetoric, religion, and magic) and in multiple forms (texts, images, and objects) then that strategy is part of a larger way of thinking. Persuasive analogy in late antiquity was used to organize knowledge, interpret experience, and thus shape it.

16 This blue glass amulet is from Cyprus, now in the British Museum in London, 1871,0123.11. 


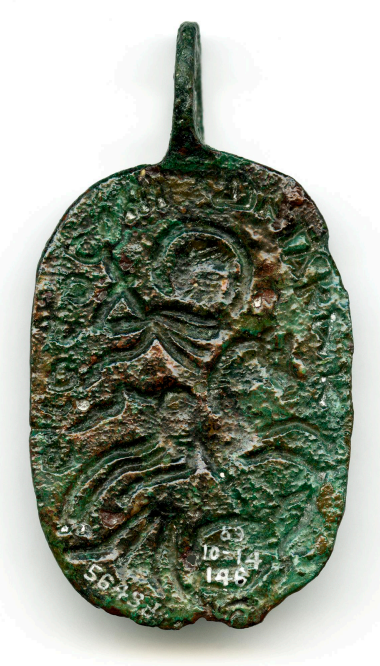

FIGURE 11 Amulet, with nimbed rider spearing prostrate figure, engraved bronze, $5.2 \times 2.7 \mathrm{~cm}$, Eastern Mediterranean, 5th-6th c., British Museum OA.9969, purchased from Rev Greville John Chester 1889 WWW.BRITISHMUSEUM.ORG/COLLECTION/OBJECT/H_OA-9969, LICENSED UNDER CC BY-NC-SA 4.0 (C) THE TRUSTEES OF THE BRITISH MUSEUM

Magical thinking functions well within communities that use persuasive analogy. Magic (along with religion and other practices of faith) is not a matter of being correct or incorrect because it is not a matter of fact, but of belief and expression. ${ }^{17}$ Furthermore, faith is not exclusive to religious authority. The very existence of the Met Museum hematite amulet contradicts the Gospel text that it reproduces: "her flow of blood was dried up in the name of her faith." Its existence suggests that, to the Byzantine amulet-wearer, faith in Jesus alone was not thought to be sufficient for a cure, and that the physical amulet with its well-chosen words and images was sought as a supplement. Faith in this case encompassed material culture - it is faith in the power of signs, words, and images. For communities that believe in the power of signs, the representation of a wish is the representation of its realization.

Rushing forward, a heroic horseman violently threatens a baby-snatching demon with a pointed blade (depicted in Fig. 13). The demon raises her head to glance directly at us as we witness her defeat. This imagery appears on

17 Tambiah 1968:175-208. 


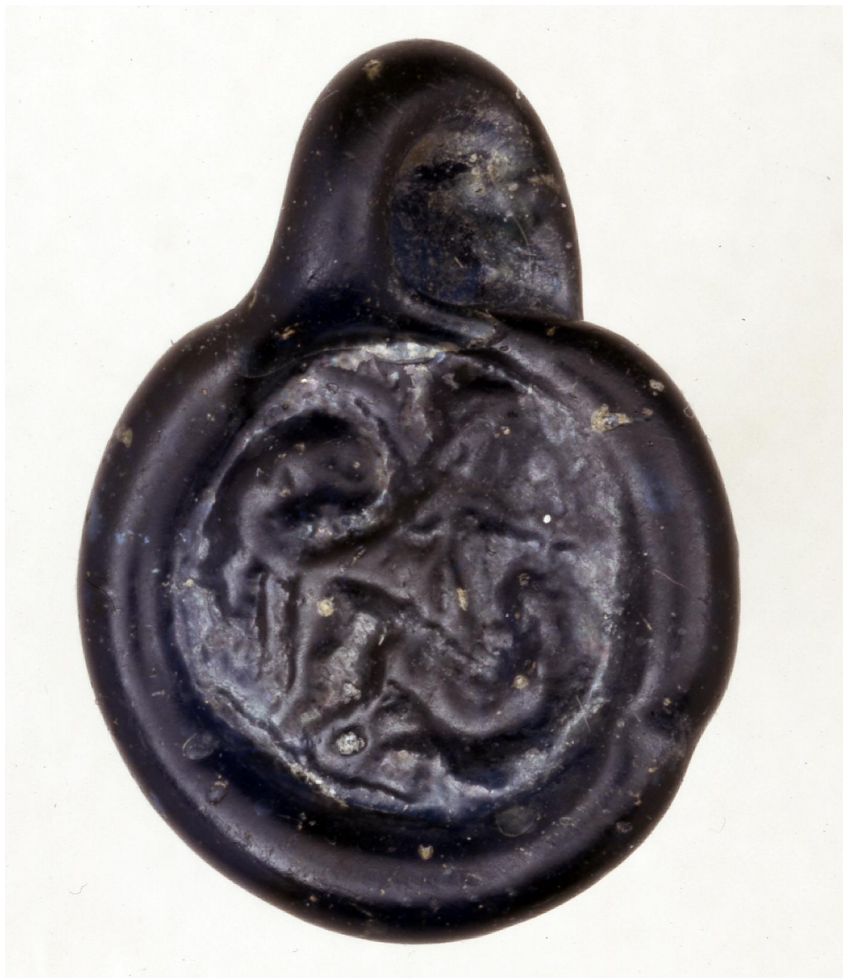

FIGURE 12 Pendant, depicting Daniel wearing a tunic, and standing in the attitude of an orans between lions, blue-colored glass, o.74 inches, Cyprus, Late Roman, 4th c., British Museum 1871,0123.11 WWW.BRITISHMUSEUM.ORG/COLLECTION/OBJECT/H_1871-0123-11, LICENSED UNDER CC BY-NC-SA 4.0 (C) THE TRUSTEES OF THE BRITISH MUSEUM

hundreds of late antique amulets, as it transforms the anxieties of parents into the deadly vengeance of a saintly hero. This is one side of a bronze amulet at the University of Michigan. Surrounding the image on this side is an inscription from the Hebrew Biblical Psalm 91: "He who dwells in the shelter of the Most High will abide in the care of the God of heaven; he will say to the Lord..."18

It continues on the other side around the edge: "Seal of the Living God, guard from all evil the one who wears this phylactery" (in Fig. 14). At the top of this other side is Jesus, and at the bottom is a lion and snake as mentioned elsewhere in Psalm 91. In between are 'ring signs,' characters whose arms terminate in tiny rings, and may signify the unintelligible speech of angels and demons. Grammatically, the psalm's plea issues a command to guard, in the

18 Psalm 9o in the Septuagint. 


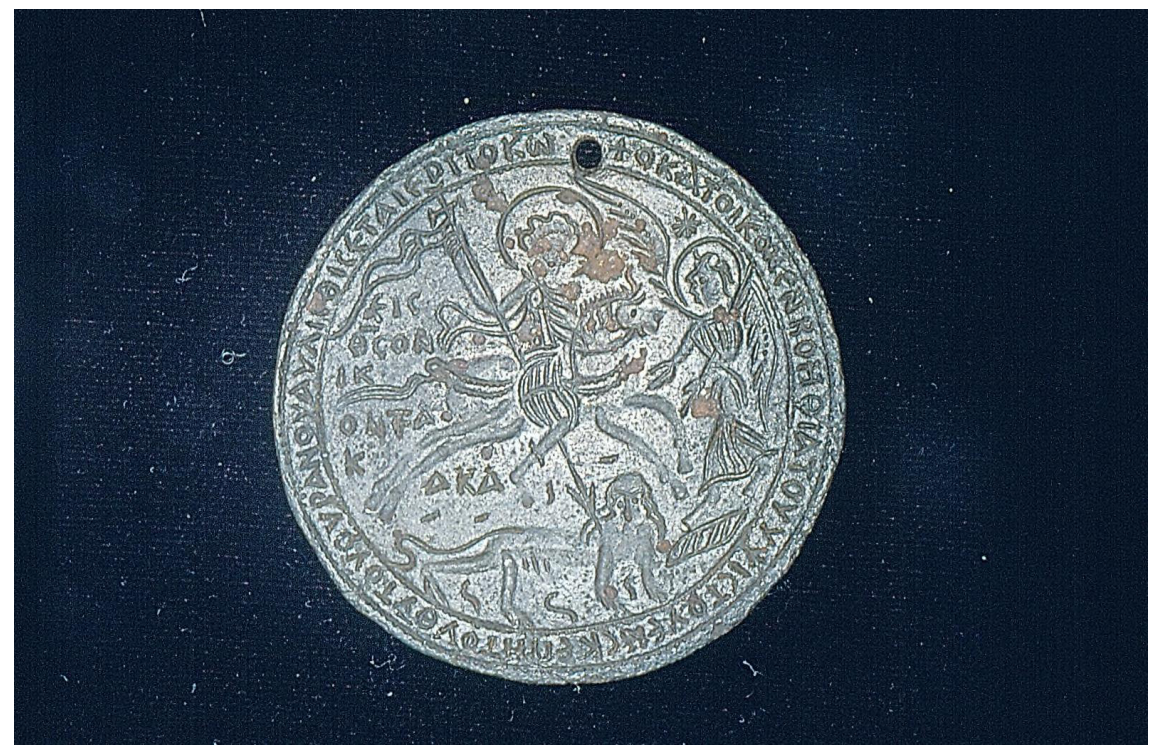

FIGURE 13 Amulet, bronze, copper, with image of a nimbed rider, find site unknown, purchased in Syria, 2nd-5th c., $5.4 \mathrm{~cm}$ dia., Kelsey Museum of Archaeology, University of Michigan, KM 2.6119

QUOD.LIB.UMICH.EDU/K/KELSEY?TYPE=BOOLEAN\&VIEW=THUMBNAIL\& RGN1=IC_ALL\&FROM=INDEX\&Q1=2.6119, REPRODUCED BY PERMISSION OF THE KELSEY MUSEUM OF ARCHAEOLOGY

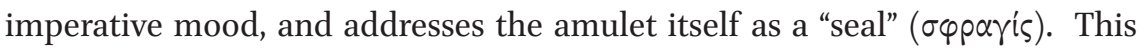
psalm is the most common psalm on amulets by far. Below the image of Jesus are the words "Hagios, hagios, hagios"..."holy, holy, holy Lord of Sabaoth" from the Hebrew Book of Isaiah 6:3; it was used on amulets and in exorcisms well before its inclusion in the Christian liturgy.

This amulet's psychological power relies on a different linguistic strategy: speech-acts: words that are the very actions that they describe.$^{19}$ For instance, the phrase 'I bet' is the action of betting, and the utterance 'I promise' is the promise itself. The inscription on the Rider amulet gives a command in direct address: "Seal of the Living God guard from all evil the one who wears this phylactery." The verb "guard" ( $\varphi \dot{\lambda} \lambda \alpha \xi \circ v$ ) directly addresses the subject of the sentence and commands it to protect a direct object, which in this case is the wearer. This inscription, the imperative form of "guard!" is a speech-act. Unlike an ordinary description, the word's power does not come from any truth-value; rather, it stems from cultural conventions and beliefs.

19 Frankfurter 2019b; Tuerk 2002:100-155; Lesses 1995:185-208, especially 189; Austin 1962:6. 


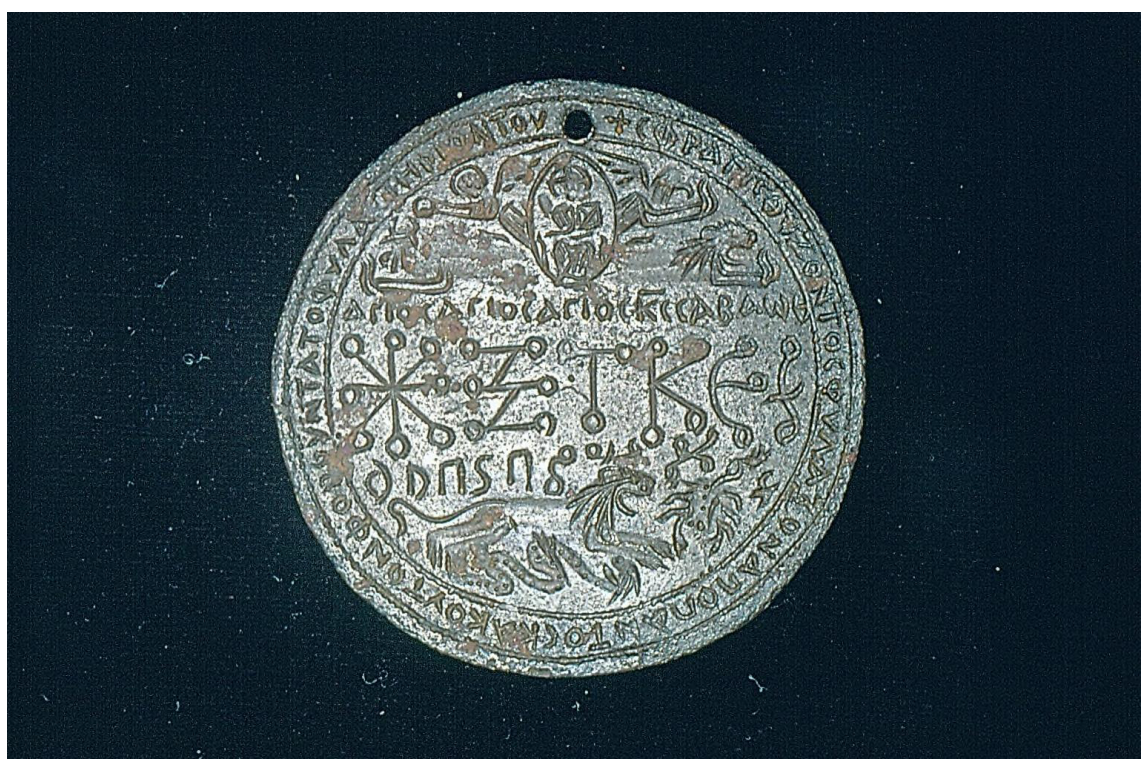

FIGURE 14 Amulet, bronze, copper, with image of Christ, ring signs, and wild beasts (the other side of fig. 13), find site unknown, purchased in Syria, 2nd-5th c., $5.4 \mathrm{~cm}$ dia., The Kelsey Museum of Archaeology, University of Michigan, KM 2.6119

QUOD.LIB.UMICH.EDU/K/KELSEY?TYPE=BOOLEAN\&VIEW=THUMBNAIL\& RGN1=IC_ALL\&FROM=INDEX\&Q1=2.6119, REPRODUCED BY PERMISSION OF THE KELSEY MUSEUM OF ARCHAEOLOGY

Collective conventions are more important than individual intentions for the power of speech-acts. This is because the power of performative acts relies on traditional and collective structures of authority, rather than on mere wishful thinking. ${ }^{20}$ Collective conventions govern individual psychologies and empower speech acts. The words and images on the Rider amulet convey meaning because of their widespread, lasting, and conventional iconographic traditions and speech acts. Speech acts in magical spells regularly use the imperative to issue commands. For example, a $5^{\text {th }}$ or 6 th century Greek papyrus utilizes the command form: "heal your handmaid who wears your name from every disease and fever and shivering....and all bewitchment and from every evil spirit." ${ }^{21}$ A love spell on a 4th century papyrus codex in Old Coptic and Greek reads: "Every flame...cause in the heart, in the liver, in the belly of

20 Lesses 1995:188 \& 192; Austin 1962:15o.

21 Now in Staatliche Museen zu Berlin, Berliner Papyrusdatenbank \#2123o, https://berlpap. smb.museum/; Meyer \& Smith 1994:\#14. 
[my beloved] so that she puts...what is in her female parts onto my male parts, quickly, quickly, quickly, immediately, immediately!"22

Images, as well as words, are capable of initiating the very actions that they depict - in this case, the defeat of a demon. Everyday performative images are familiar to us in religious rituals, patriotic displays, and pornography. Just as there are speech acts, so also there are show-acts. The image of a triumphant horseman over a trampled demon on this Rider amulet more than describes a threat; it delivers that threat to its supposed demonic audience. But as with any language, this image is an oppressive act only if the human user believes in the effectiveness of the image.

Together, the words and images on the Rider amulet initiate the very actions that they depict by synthesizing signifier and referent. Show-acts do more than represent; they present, just as Byzantine icons were commonly believed to embody the holy people that they depict. ${ }^{23}$ Byzantine authors regularly tell of depicted subjects acting upon actual objects - of icons talking, bleeding, and crying (as subjects) toward actual objects whom they advise, kill, or heal. Beliefs about icons circulated through larger conceptual schemes regarding the power of images in general. ${ }^{24}$ These larger conceptual schemes apply to amulets as well. The Rider amulet semantically constructs relationships between depicted agents and actual objects, presenting its actions beyond mere representation. On one side of the Rider amulet is depicted three wild beasts (a lion, scorpion, and snake) that, according to the 3rd-century Greek text, The Testament of Solomon, defeat the Evil Eye. The amulet's text, "Seal of the Living God protect the wearer from all evil," corroborates this iconography. Yet the Evil Eye itself is not depicted. The amulet also shows Jesus giving a blessing, but not the person receiving it. And lastly, the ring signs are addressed to someone powerful, an assumed demonic or angelic presence that is, again, not depicted. The things not present in the image were understood to exist in the world outside of the depiction. The actions of the depicted subjects upon actual objects or audiences constitute show-acts.

The language of amulets and holy icons, and indeed ordinary language, function through the same late antique ways of perceiving and knowing. The late antique author, Sophronius (ca. 56o-638 CE), writes about a man named Theophilus who suffered pain in his limbs and was visited in a dream by the doctor saints, Cyrus and John. The saints instructed Theophilus to find a

\footnotetext{
22 In Paris Bibliothèque Nationale, GMP 1.70-77 "Great Magical Papyrus of Paris," 4th century; Meyer and Smith 1994:\#3.

23 Tuerk 2008.

24 Tuerk 2005.
} 
hidden statue of himself that had pins in it, and after pulling out the pins, his pain was relieved..$^{25}$ An eight-sided ring was recommended by the late antique Greek physician, Alexander of Tralles, as a remedy for stomach pain, trusting in the curative powers of the 8 -sided shape itself. ${ }^{26}$ In certain late antique Mediterranean communities, demons were regarded as real agents of actual deeds. They were also regarded as being able to be slain by effective opponents, namely the powerful words and images that were believed to dominate them.

We can never know to what extent someone found physical healing or well-being while wearing an amulet - but it is certain that people's psychological well-being was affected. Why else would thousands of these objects have been made, if not for communities of believers who bought and used them?

I have outlined only a few semiotic strategies for magical thinking: persuasive analogy, speech acts, and show acts. But these are just a small part of exploring how linguistic structures shaped human experience.

At its heart, magic studies is interdisciplinary because late antique Mediterranean magical thinking was widespread across various social practices. However, future studies must evolve ways to integrate different disciplines more seamlessly. These academic disciplines (such as history, linguistics, and archaeology) each have different academic priorities. Magic studies call for a change in the modern scholarly assumptions regarding structures of authority, which have until now shaped a typical understanding of late antiquity. Magic studies also calls for acute attention to modern scholars' conflicting worldviews within our own notions of authority, and an insistence on self-critique of our intellectual colonization of times past. Self-critique is the allure of magic. Magic is an exploration of our powerlessness, but it is also an exploration of how we create our own power.

\section{References}

Abrahamse, Dorothy (1982). Magic and Sorcery in the Hagiography of the Middle Byzantine Period. Byzantinische Forschungen 8, pp. 3-17.

Austin, J. L. (1962, rpt. 1968). How to do Things with Words. Oxford: Oxford University Press.

Berry, George Ricker (1943). The Interlinear Literal Translation of the Greek New Testament. Grand Rapids: Zondervan Publishing House.

25 See Magoulias (1967-68:236-237) for several examples including the Cyrus and John story.

26 Vikan 1982:43. 
Betz, Hanz Dieter, ed. (1986). The Greek and Demotic Papyri in Translation. Chicago: University of Chicago Press.

Bohak, Gideon (2008). Ancient Jewish Magic: A History. Cambridge: Cambridge University Press.

Bohak, Gideon (1996). Traditions of Magic in Late Antiquity. Ann Arbor: Kelsey Museum, University of Michigan. www.hti.umich.edu/exhibit/magic.

Bol, Peter, Beck, Herbert, and Stutzinger, Dagmar, eds. (1983). Spätantike und frühes Christentum: Ausstellung im Liebieghaus Museum Alter Plastik, Frankfurt am Main: 16 Dezember 1983 bis 11 März 1984. Frankfurt am Main: Das Liebieghaus.

Bonner, Campbell (1950). Studies in Magical Amulets, Chiefly Graeco-Egyptian. Ann Arbor: University of Michigan.

Bortolani, Ljuba M., Furley, William, Quack, Joachim Friedrich, and Nagel, Svenja, eds. (2019). Cultural Plurality in Ancient Magical Texts and Practices. Tübingen: Mohr Siebeck.

Boschung, Dietrich, and Bremmer, Jan N., eds. (2015). The Materiality of Magic. Paderborn: Wilhelm Fink.

Bosselmann-Ruickbie, Antje (2019). Protection against Evil in Byzantium: Magical Amulets and Their Survival from the Early to the Late Byzantine Period. In: D. Zamani, J. Noble, and M. Cox, eds., Visions of Enchantment: Occultism, Magic and Visual Culture, Lopen: Fulgur Press, pp. 16-37.

Bozóky, Edina (2003). Charmes et prières apotropaïques. Turnhout: Brepols.

Branham, Joan R. (2002). Bloody Women and Bloody Spaces: Menses and the Eucharist in Late Antiquity and the Early Middle Ages. Harvard Divinity Bulletin 30 (4), pp. $15^{-22 .}$

Budge, E. A. Wallis (2011). Amulets and Magic. London and New York: Routledge.

Daniel, Robert, and Maltomini, Franco, eds. (1990). Supplementum Magicum. Opladen: Westdeutscher Verlag.

Dasen, Véronique (2014). Healing Images, Gems and Medicine. Oxford Journal of Archaeology 33 (2), pp. 177-191.

Dasen, Véronique, and Spieser, Jean-Michel, eds. (2014). Les savoirs magiques et leur transmission de l'Antiquité à la Renaissance. Florence: Sismel Edizioni del Galluzzo.

De Bruyn, Theodore (2017). Making Amulets Christian: Artefacts, Scribes, and Contexts. Oxford: Oxford University Press.

Dickie, Matthew W. (2001). Magic and Magicians in the Greco-Roman World. New York: Routledge.

Entwistle, Chris (2003). Through a Glass Brightly: Studies in Byzantine and Medieval Art and Archaeology Presented to David Buckton. Oxford: Oxbow.

Entwistle, Chris, and Adams, Noël, eds. (2011). Gems of Heaven: Recent Research on Engraved Gemstones in Late Antiquity. London: Trustees of the British Museum. 
Faraone, Christopher (1999). Ancient Greek Love Magic. Cambridge: Harvard University Press.

Faraone, Christopher (2012). Vanishing Act on Ancient Greek Amulets: from Oral Performance to Visual Design. London: University of London.

Faraone, Christopher (2018). The transformation of Greek Amulets in Roman Imperial Times. Philadelphia: University of Pennsylvania Press.

Faraone, Christopher, and Obbink, Dirk (1991). Magika Hiera: Ancient Greek Magic \& Religion. Oxford: Oxford University Press.

Fögen, Marie Theres (1995). Balsamon on Magic: From Roman Secular Law to Byzantine Canon Law. In: H. Maguire, ed., Byzantine Magic, Washington, D.C.: Dumbarton Oaks, pp. 99-116.

Frankfurter, David, ed. (2019a). Guide to the Study of Ancient Magic. Leiden: Brill.

Frankfurter, David (2019b). Spell and Speech Act. In: D. Frankfurter, ed., Guide to the Study of Ancient Magic, Leiden: Brill, pp. 6o8-625.

Kitzinger, Ernst (1954). The Cult of Images before Iconoclasm. DOP 8, pp. 83-150.

Kotansky, Roy (1994). Greek Magical Amulets: The Inscribed Gold, Silver, Copper and Bronze Lamellae. Opladen: Westdeutscher Verlag.

Lesses, Rebecca (1995). The Adjuration of the Prince of the Presence: Performative Utterance in a Jewish Ritual. In: M. Meyer \& P. Mirecki, eds., Ancient Magic and Ritual Power, New York: Brill, pp. 185-206.

Magoulias, Harry (1967-68). Lives of Byzantine Saints as Sources for Data for the History of Magic in the Sixth and Seventh Centuries. Byzantion 37, pp. 228-269.

Maguire, Eunice Dauterman, Maguire, Henry, and Duncan-Flowers, Maggie (1989). Art and Holy Powers in the Early Christian House. Champaign, IL: University of Illinois Press.

Maguire, Henry, ed. (1995). Byzantine Magic. Washington, D.C.: Dumbarton Oaks.

Mathews, Thomas (1999). The Clash of Gods: A Reinterpretation of Early Christian Art - Revised and Expanded Edition. Princeton: Princeton University Press.

Meyer, Marvin, and Mirecki, Paul, eds. (1995). Ancient Magic and Ritual Power. New York: E.J. Brill.

Meyer, Marvin, and Smith, Richard (1994). Ancient Christian Magic: Coptic Texts of Ritual Power. San Francisco: Harper.

Michel, Simone (2001). Magischen Gemmen im Britischen Museum. London: British Museum.

Migne, J.-P., ed. (1862). Patrologiae Cursus Completus, Series Latina, Volume 77. Paris: Garnier Fratres.

Mirecki, Paul, and Meyer, Marvin, eds. (2001). Magic and Ritual in the Ancient World. Leiden: Brill. 
Nagy, Árpád M., Endreffy, Kata, and Spier, Jeffrey, eds. (2019). Magical Gems in Their Contexts. Budapest: L'Erma di Bretschneider.

Patera, Maria (2006). Gylou, démon et sorcière du monde byzantine au monde néogrec. Revue des étude byzantines 64, pp. 311-327.

Peers, Glenn, with Roggema, Barbara (2018). Orthodox Magic in Trebizond and Beyond: A Fourteenth-century Greco-Arabic Amulet Roll. Seyssel: La Pomme d'or.

Pliny the Elder (23/24-79 CE). Natural History. In: H. Rackham et al. (1938-63), Loeb Classical Library, Cambridge: Harvard University Press.

Regulski, Ilona, Duistermaat, Kim, and Verkinderen, Peter, eds. (2012). Seals and Sealing Practices in the Near East: Developments in Administration and Magic from Prehistory to the Islamic Period. Leuven: Uitgeverij Peeters en Departement Oosterse Studies, pp. $115^{-132 .}$

Shaked, Shaul, ed. (2005). Officina Magica: Essays on the Practice of Magic in Antiquity. IJS Studies in Judaica 4. Leiden: Brill.

Smith, Jonathan (1990). Drudgery Divine: On the Comparison of Early Christianities and the Religions of Late Antiquity. London: University of London.

Smith, Morton (1978).Jesus the Magician. San Francisco: Harper and Row.

Soranus of Ephesus (b. 98 CE). Gynaecia. In: F. Reinhold Dietz and V. Rose (1991), Sorani Gynaeciorum vetus translatio latina, Leipzig: B.G. Teubneri. Also in: J. Ilberg and E. Kind, eds. (1927), Sorani Gynaeciorum, Leipzig: Berolini. Also in: O. Temkin (1991), Soranus' Gynecology, Baltimore: Johns Hopkins University Press.

Spier, Jeffrey (2007). Late Antique and Early Christine Gems. Wiesbaden: Reichert Verlag.

Tambiah, Stanley (1968). The Magical Power of Words. Man: The Journal of the Royal Anthropological Institute 3 (2), pp. 175-208.

Tuerk, Jacquelyn (1999). An inscribed Byzantine amulet and its narratives. Byzantine and Modern Greek Studies 23, pp. 24-42.

Tuerk, Jacquelyn (2002). How To Do Things with Words and Images in Late Antiquity and the Early Middle Ages. University of Chicago, PhD dissertation.

Tuerk, Jacquelyn (2005). Breaking through the Picture Plane: Icons, Verbal Performance, and Magical Amulets. In: A. Lidov, ed, Comparative Hierotopy: Studies in the Making of Sacred Space, Volume 1, Moscow: Research Centre for Eastern Christian Culture.

Tuerk, Jacquelyn (2008). Hierotopy, Narrative, and Magical Amulets. In: A. Lidov, ed, Comparative Hierotopy: Studies in the Making of Sacred Space, Volume 2, Moscow: Research Centre for Eastern Christian Culture.

Vikan, Gary (1982). Byzantine Pilgrimage Art. Washington, D.C.: Dumbarton Oaks. Vikan, Gary (1984). Art, medicine, and magic in early Byzantium. Dumbarton Oaks Papers 38, pp. 65-86. 
Walker, Alicia (2002). Myth and magic in early Byzantine marriage jewelry: The persistence of pre-Christian traditions. In: A. McClanan and K. Encarnación, eds, The Material Culture of Sex, Procreation, and Marriage in Premodern Europe, New York: Palgrave, pp. 59-78.

Weitzmann, Kurt, ed. (1979). Age of Spirituality: Late Antique and Early Christian Art, Third to Seventh Century; Catalogue of the Exhibition at the Metropolitan Museum of Art, November 1977 - February 1978. New York: Metropolitan Museum of Art. 